Abas, Urgensi Etika dalam Tata Kelola Pemerintahan...

\title{
URGENSI ETIKA DALAM TATA-KELOLA PEMERINTAHAN (GOVERNANCE)
}

\author{
Abas \\ Program Studi Administrasi Publik, Fakultas Ilmu Sosial dan Politik, Universitas Bandar Lampung \\ Email: ab3_male@yahoo.com
}

\begin{abstract}
Abstrak
Munculnya studi etika, dalam tataran teoritis, khususnya dari perspektif administrasi publik, terlihat dari adanya evolusi perhatian pemikiran administrasi secara bertahap bergeser dari murni struktural danaspek fungsional dariorganisasi dan manajemen untuk pertanyaan tentang kepemimpinan dan motivasi awalnya dan kemudian bergeser ke studi perilaku yang tepat atas dasar standar etika dan normatif tertentu. Begitupun dengan adanya penetrasi aspek politik ke administrasi publik, atau dari sekedar implementasi ke formulasi. Dengan demikian, etika publik diperlukan dalam rangka membangun etika tidak hanya di lingkungan birokrasi pemerintah (eksekutif) melainkan juga lembaga politik, maupun lembaga negara lainnya. Hal ini penting, mengingat praktik atau perilaku pelanggaran etika publik seperti halnya korupsi dapat terjadi pada semua level pemerintahan saat ini, baik korupsi politik maupun korupsi di level birokrasi.
\end{abstract}

Kata Kunci: Etika, Tata Kelola

\begin{abstract}
The emergence of ethical studies, on a theoretical level, in particular from the perspective of public administration, is evident from the evolution of attention of administrative thought gradually shifting from the purely structural and functional aspects of the organization and management to questions about leadership and motivation initially and then shifting to the study of appropriate behavior on the basis of standard ethics and normative. Likewise with the penetration of political aspects into the public administration, or from just the implementation to the formulation. Thus, public ethics is needed in order to build ethics not only in government bureaucratic environment (executive) but also political institutions, as well as other state institutions. This is important, given the practice or behavior of public ethical violations as well as corruption can occur at all levels of government today, both political corruption and corruption at the bureaucratic level.
\end{abstract}

Keywords: Ethics, Governance.

\section{PENDAHULUAN}

Salah satu tantangan serius yang dihadapi umat manusia dalam kehidupan sosial yang terorganisir adalah etika - yaitu, masalah pilihan antara yang baik dan yang buruk, lakukan dan jangan lakukan. Semua kreasi di alam ini mengikuti hukum alam tertentu. Itu sebabnya kita bisa secara tepat memprediksi kapan matahari akan terbit besok. Tapi kita tidak bisa memprediksi perilaku manusia dengan cara yang sama. Tidak ada yang bisa dengan begitu meyakinkan mengatakan bahwa dua individu akan berperilaku sama besok seperti yang mereka lakukan hari ini, karena manusia telah dianugerahi kebebasan untuk melakukannya. Itulah sebabnya filsuf dan ilmuwan telah menekankan perkembangan etika manusia untuk memastikan perilaku rasional di masyarakat (Noor, 2008). Heynes (1986: 01), berpendapat bahwa etika berkaitan dengan tindakan manusia. Hal ini berhubungan dengan perilaku baik atau buruk, benaratau salah. Etika mengevaluasi perilaku dengan beberapa kriteria absolut dan menempatkan kriteria nilai negatif atau positif atasnya (Hanekom, 1984: 58).
Apa yang menjadi inti dari etika, menurut Uhr adalah keadilan (Uhr, 1988). Kata keadilan paralel dalam bahasa Yunani "dikeia", yang berarti konvensi, hukum dan penilaian yang baik, benar dan adil (Gulet, 1983). Oleh karena itu, orang yang jujur-adil adalah orang yang perilakunya mencerminkan semua kualitas etis tersebut.

Buruknya kinerja penyelenggaraan negara adalah lebih disebabkan karena etika jauh dari ruang publik. Etika tidak menjadi basis nilai kontrol bagi kekuasaan itu sendiri. Padahal kekuasaan tanpa etika akan melahirkan apa yang disebut sebagai "abuse of power", baik di level eksekutif maupun legislatif. Abuse of power bentuknya dapat bermacam-macam: korupsi, kolusi, nepostism, pemberian layanan yang tidak sesuai standar etika maupun efisiensi dan efektifitas kebijakan. Korupsi, dalam praktik pengelolaan pemerintahan, terjadi pada dua aspek : Pembuatan keputusan dan pelaksanaan program pemerintah. Pembuatan keputusan atau program seringkali didasarkan pada kepentingan pribadi atau kelompok pendukung. Dalam tataran praktis, khususnya di Indonesia, maraknya praktik administrasi yang menyimpang atau yang dikenal dengan Mal-Administrasi dan maraknya perilaku dan praktik korupsi yang 
dilakukan penyelenggara negara telah menginisiasi kelahiran beberapa produk hukum tentang etika penyelenggara negara.

Implementasi etika dalam sektor publik, dengan demikian menjadi penting karena beberapa alasan, baik filosofis maupun prakmatis. Dari aspek filosofis, sektor publik berbeda dengan sektor privat. Dalam sektor publik, pentingnya nilai-nilai dan etika dalam kepemimpinan dan governance dalam pelayanan publik lebih ditekankan. Ini ditunjukkan bahwa kepemimpinan dan proses penyelenggaraan pemerintahan dalam pelayanan publik tidak bisa sekedar berasal dari pengalaman di sektor swasta, karena adanya perbedaan baik dalam sifat dan ruang lingkup lingkungan maupun fungsi masing-masing sektor tersebut. Sektor publik berada pada lingkungan politik di mana pelayanan publik yang dilakukan oleh penyelenggara negara memerlukan pemeriksaan ulang terkait dengan etika publik (Sindane, 2011). Karenanya, dalam teori pelayanan publik, dikenal sebuah maklumat baku bahwa : public services is public trust.

Lahirnya studi etika dengan demikian memiliki tujuan dan kepentingan langsung dengan penyelenggara negara dan masyarakat itu sendiri, sebagai penerima layanan. Dari aspek penyelenggara negara, khususnya pemimpin politik saat ini dalam rangka melakukan fungsi mengontrol etika dan akuntabilitas dalam praktik penyelenggara negara. Sebagai contoh misalnya, korupsi dapat terjadi manakala pemimpin tidak memiliki kontrol atau tersedianya mekanisme kontrol. Fungsi Kontrol dari kepemimpinan sendiri dapat diwujudkan manakala terdapatnya pengetahuan dan akses informasi yang memadai.

Di sisi lain, studi etika juga memiliki relevansi bagi kepentingan langsung masyarakat secara umum dalam kaitannya dengan upaya mendorong terciptanya penyelenggaraan pemerintahan yang beretika. Sektor publik sangat luas dan kompleks menjadi tantangan sendiri. Tantangan inikhususnya dapat dilihat di mana sebagian besar anggota masyarakat tidak memiliki pemahaman yang banyak terkait dengan urusan pemerintahan, padahal di sisi lain, mereka mengharapkan seharusnya penyelenggara negara dapat memiliki akuntabilitas yang memadai. Masyarakat tidak memiliki pengetahuan tentangtujuan maupun informasi terbaru tentang apa yang terjadi di sektor publik. Hal ini pada gilirannya akan menjadi hambatan bagi mereka untuk melakukan kontrol langsung terhadap akuntabilitas dan proses pemerintahan yang sedang berjalan. Padahal seperti di katakan Radhika (2011) bahwa pengetahuan dan informasi adalah dua prasyarat untuk melakukan kontrol langsung tersebut. Selain sekedar kepatuhan, nilai-nilai, akuntabilitas danetika dapat dianggap sebagai mekanisme kontrol baik politikpara pengurusnya dan pejabat yang ditunjuk dalam mengejar moral mereka dalam mewujudkankesejahteraan umum. Radhika dengan tegas mengatakan : "Hal ini juga penting bahwa masyarakat dididik tentangkonsep dan teori-teori nilainilai yang mendukung, akuntabilitas danetika,yang memungkinkan mereka dalam mengontrol perwakilan politik (pejabat politik) dan pejabat publik (pejabat karir) yang mewakili mereka untuk lebih bertanggung jawab (A.M. Sindane, 2011: 751).

Akan tetapi, meskipun etika penting dalam kehidupan publik saat ini, terdapat tantangan atau kendala yang harus diselesaikan saat ini, sebagaimana disebutkan Menzel (2010), tantangan pertama yakni kurangnya pemahaman dan kesadaran pentingnya etika dalam melaksanakan pekerjaan pemerintah dan kemudian bertindak atas pemahaman itu. Kendala kedua adalah kurangnya kesadaran manajemen puncak (pimpinan) tentangkelakuan yang buruk. Hal ini misalnya terlihat bahwa banyak pejabat tingkat tinggi tidak tahu apa yang terjadi diorganisasi mereka. Kendala ketiga adalah terkait dengan sejarah dan budaya. Kendala keempat adalah "buta huruf" etis. Pemimpin dan pengikut yang tidak mampu "untuk memahami sepenuhnya seluk-beluk masalah etika yang kompleks dan untuk melihat semua konsekuensi tentang tindakan seseorang".

Sehubungan dengan latar belakang di atas, maka pertanyaan penelitian ini ialah :

1. Bagaimana tata kelola pemerintahan daerah di Indonesia?

2. Bagaimana peran Komisi Aparatur Sipil Negara (KASN) dalam menegakkan etika Aparatur Sipil Negara dalam memberikan pelayanan publik?

\section{METODE}

Jenis penelitian ini ialah studi pustaka (desk research) yang dilakukan selama bulan Desember 2016 hingga April 2017. Jenis penelitian ini ialah kualitatif dengan menghasilkan data deskriptif. Bogdan dan Taylor dalam Moleong (2000) menyatakan bahwa "metode kualitatif sebagai prosedur penelitian yang menghasilkan data deskriptif berupa kata-kata tertulis atau lisan dari orang-orang dan perilaku yang dapat diamati”. Penelitian ini menggunakan beberapa dokumen seperti buku, jurnal ilmiah, artikel ilmiah dan populer sebagai referensi utama dalam memperoleh data utama dan menganalisis data tersebut.

Penelitian ini menggunakan analisis data interaktif. Miles dan Huberman (1992) memberikan 4 (empat) tahap analisis data yaitu :

1. Pengumpulan data, yaitu mengumpulkan semua data.

2. Reduksi data, merupakan proses pemilihan dan penyortiran data.

3. Penyajian data, peneliti dapat melihat data yang diperoleh secara utuh.

4. Penarikan kesimpulan dilakukan secara induktif.

\section{HASIL DAN PEMBAHASAN}

\section{Tanggung jawab Kepemimpinan dan Menjaga kepercayaan Publik}

Salah satu tanggung-jawab utama pemerintah adalah membangun lingkungan keadilan dan aturan hukum, kejujuran, transparansi dan kepercayaan. Dalam masyarakat demokratis, pemerintah akan gagal jika tidak membawa kepercayaan publik ini (Murray 1997). Munculnya berita kasus penerimaan sogokan oleh anggota parlemen dan tidak mengikuti standar perilaku politik yang dapat diterima oleh pejabat terpilih sangat 
merusak tanggung jawab utama pemerintah untuk membangun lingkungan kepercayaan antar institusipemerintah dan warga negara. Penurunan kepercayaan publik pada pemimpindi seluruh dunia dapat dikaitkan dengan kepemimpinan yang buruk dan pertumbuhan korupsi dan ketidak-jujuran dalam politik (Nye 1997). Oleh Karena itu, pemahaman yang lebih lengkap tentang penurunan ini dapat diperoleh dengan memeriksa kepercayaan publik terhadap pemerintah.

Tingkat kepercayaan masyarakat terhadap pemerintah dipengaruhi oleh beberapa faktor termasuk ekonomi, budaya dan politik. Fukuyama mengartikulasikan, "kesejahteraan suatu bangsa dan jugakemampuannya untuk berkompetisi dikondisikan oleh satu karakteristik budaya yang luas, yaitu tingkatkepercayaan di masyarakat "(Fukuyama 1995). Berman melihat kepercayaan sebagai ukuran kondisi sosio-ekonomidan berpendapat, bahwa "Kondisi masyarakat yang negatif, seperti stagnasi ekonomi,pendapatan yang rendah dan perselisihan rasial mengurangi sumber daya ekonomi dan politik dan berkontribusi pada sebuah ketidak-percayaan terhadap pemerintah (Berman 1994).DiPiazza dan Eccles (2002: 34), menyebutkan dua elemen kunci kepercayaan publik yakni semangat transparansi dan budaya pertanggungjawaban. Hal ini penting, karena mereka menafsirkan makna pemerintahan yang tepat kepada publik. Kepercayaan publik dicapai ketika institusi dan agen pemerintah mampu menyelesaikan tugas atau tanggung jawab utama mereka, memenuhi impian masyarakat, dan menciptakan masyarakat atau individu yang ideal atau perlunya transformasi.

Beberapa tahun yang lalu Indonesia Governance Index (IGI) merilis indeks hasil tata kelola pemerintah daerah versi IGI tahun 2014 yang merupakan hasil survey dari 34 kabupaten/kota di seluruh Indonesia. Nilai tertinggi diraih kota Yogyakarta dengan nilai 6,85 dari skala maksimal 10 terhadap tata kelola dan pembangunan daerah. IGI merupakan alat untuk mengukur kinerja pemerintahan daerah, khususnya terhadap empat arena pemerintahan yaitu arena pemerintah (legislatif dan eksekutif), birokrasi, masyarakat sipil, dan masyarakat ekonomi berdasarkan beberapa kriteria data yang obyektif dan terukur. Beberapa hal yang dilihat dari prinsip partisipasi, akuntabilitas, transparansi, efisiensi, efektivitas, dan keadilan.

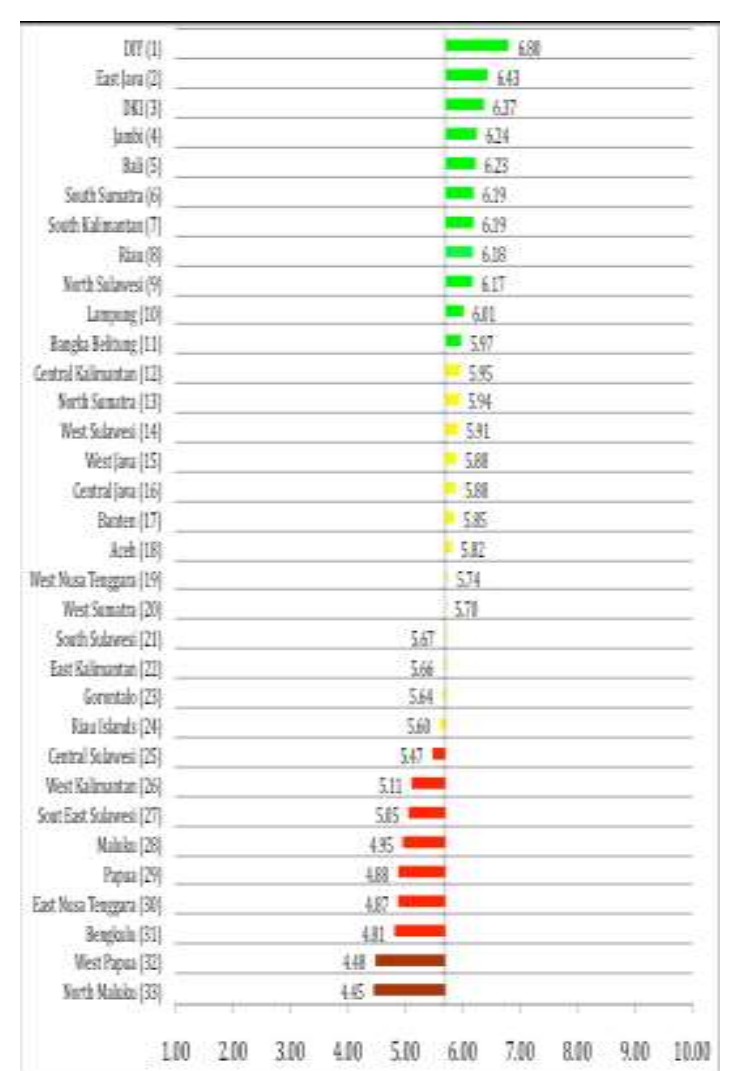

Gambar. 1. Indeks Tata kelola Pemerintahan di Indonesia

Krisis kepercayaan publik terhadap kinerja pemimpin baik di sektor swasta maupun publik memunculkan ketertarikan kajian tentang manajemen etika. Seperti disebutkan Mihelič, Lipičnik, dan Metka Tekavčič (2010), Hanya dalam beberapa tahun terakhir bahwa manajer dan peneliti telah mengalihkan perhatian mereka ke manajemen etika (L. K. Trevino \& Brown, 2005). Perhatian untuk "kesadaran etis" datang pada saat konsep legitimasi kepemimpinan dipertanyakan dan ketika kepercayaan publik dalam tata kelola perusahaan sangat rendah (Fulmer, 2005). Munculnya apa yang disebut sebagai mal administrasi adalah salah satu contoh yang ditunjukkan Nigro dan Nigro (2012) :

1. Ketidak jujuran (dishonesty), yaitu suatu tindakan administrasi yang tidak jujur (Pungli);

2. Perilaku yang buruk (unethical behaviour),(contoh: perekrutan pegawai baru ada istilah surat sakti (catebalace); Nepotisme).

3. mengabaikan hukum (disregard of the law), pegawai (administrator publik) dapat mengabaikan hukum atau membuat tafsiran hukum yang menguntungkan kepentingannya. Misalnya pegawai menggunakan mobil dinas untuk keluarga; dsb.

4. Favoritisme dalam menafsirkan hukum (pejabat atau pegawai di suatu instansi tetap mengikuti hukum yang berlaku, tetapi hukum tersebut ditafsirkan untuk menguntungkan kepentingan tertentu). 
5. Perlakuan yang tidak adil terhadap pegawai. Misalnya pimpinan menghambat pegawai yang berprestasi karena merasa disaingi;

6. Inefisiensi bruto (gross inefficiency), Misalnya pemborosan dana secara berlebihan;

7. Menutup-nutupi kesalahan.

8. Gagal menunjukkan inisiatif. Gagal membuat keputusan yang positif atau menggunakan diskresi (keleluasaan/kelonggaran) yang diberikan

Dalam kasus penyelenggaraan pemerintahan di Indonesia, sebagaimana hasil audiensi dengan beberapa pakar, kementerian PAN, maupun ARB dengan Komite I DPD RI pada tahun 2017, dapat ditemukan gejala-gejala pelanggaran etika baik di lingkungan Aparatur Sipil Negara, Maupun Pejabat Politik.

1. Degradasi moral penyelenggara negara

Maraknya sikap dan perilaku penyelenggara negara yang mengabaikan penghormatan dan ketaatan terhadap nilai-nilai moral \& prinsip dasar atau norma etika.

\section{Kebohongan publik}

Seringkali dijumpai sikap, perilaku, tindakan dan ucapan penyelenggara negara yang melakukan pembohongan kepada publik dan tidak jujur dalam menyampaikan fakta yang sebenarnya dilapangan.

3. Konflik kepentingan

Penyelenggara negara dalam melaksanakan tugas dan kewenangan sering menimbulkan konflik kepentingan antara kepentingan pribadi, keluarga dan kelompok dengan kepentingan negara seperti perangkapan jabatan, pengadaan barang dan jasa.

4. Intervensi proses peradilan

Penyelenggara Negara seringkali bersikap dan bertindak yang dapat mempengaruhi proses penyelesaian perkara di peradilan.

5. Pembuatan kebijakan yang berakibat pemborosan sumber daya Seringkali penyelenggara negara membuat kebijakan dan program kegiatan yang tidak memperhitungkan efisiensi penggunaan sumber daya (man, money, material and time)

6. Pengangkatan pejabat yang tidak kompeten. Serikali penyelenggara negara mengangkat seseorang dalam jabatan yang tidak memperhatikan kompetensi atau tanpa pertimbangan yang dipersyaratkan oleh jabatan.

7. Kurang tanggap/responsif dalam memberikan pelayanan

Penyelenggara Negara seringkali bersikap dan berperilaku kurang sopan dan santun serta acuh tak acuk dalam memberikan pelayanan kepada masyarakat.

8. Perlakuan deskriminatif

Dalam memberikan pelayanan umum penyelenggara negara sering bersikap diskriminatif, mementingkan kepentingan pribadi serta memberikan perlakuan khusus kepada kerabat, keluarga dan kelompok.

9. Kurangnya kepedulian terhadap lingkungan.

Sering kali terjadi sikap, perilaku dan tindakan penyelenggara negara yang tidak peduli dan mempertimbangkan situasi dan kondisi lingkungan. Hal ini terutama banyak terlihat dalam kasus-kasus pembuatan kebijakan publik.

Di lingkungan ASN sendiri, sebagaimana dikemukakan KASN dapat rapat bersama dengan Komite I DPD RI memperlihatkan masih buruknya sikap ASN dalam penyelenggaraan negara. Dari laporan yang diterima dan diproses ASN saja sudah memperlihatkan banyaknya kasus yang ditangani. Belum lagi dengan kasus-kasus lain yang serupa dan tidak dilaporka, tentu lebih banyak lain. Contoh ini hanyalah seperti fenomena gunung es dimana yang tampak ke permukaan hanyalah sedikit, sedangkan yang tidak tampak atau diadukan langsung ke KASN adalah sangat banyak.

Tabel. 1. Pengaduan yang diterima KASN tahun 2016.

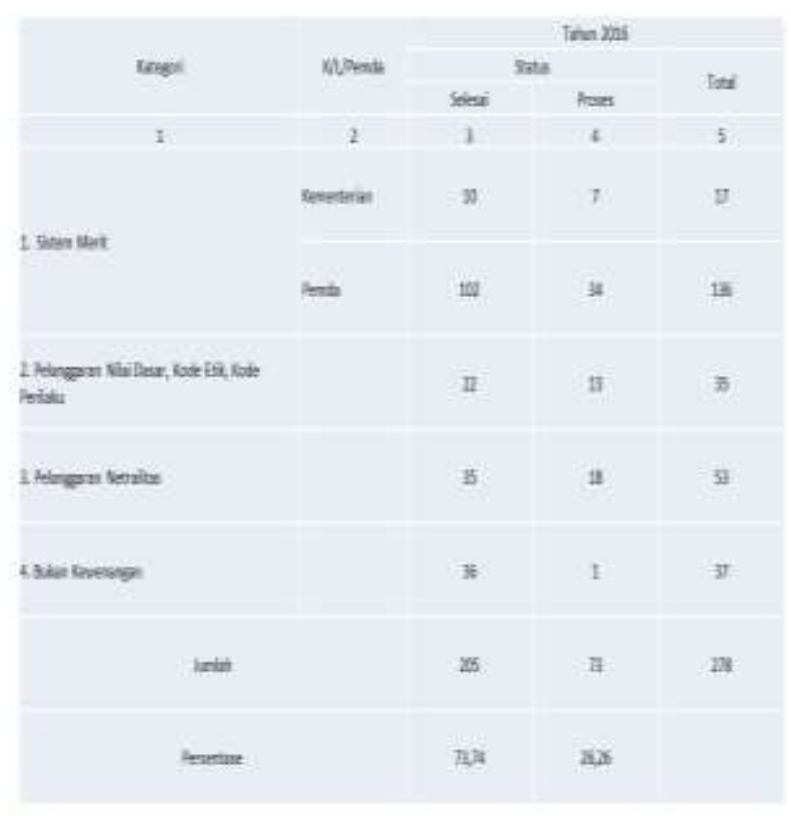

Sumber: KASN, 2017.

Dengan demikian, etika publik diperlukan dalam rangka membangun etika tidak hanya di lingkungan birokrasi pemerintah (eksekutif) melainkan juga lembaga politik, maupun lembaga negara lainnya. Hal ini penting, mengingat praktik atau perilaku pelanggaran etika publik seperti halnya korupsi dapat terjadi pada semua level pemerintahan saat ini, baik korupsi politik maupun korupsi di level birokrasi. Sebagaimana Amundsen dan Andrade (2009) membedakan kedua jenis korupsi tersebut. Korupsi politik melibatkan pembuat keputusan politik. korupsi politik atau sering berlangsung di tingkat sistem politik. Ini sering terjadi ketika para politisi dan agen negara, yang berhak untuk membuat dan menegakkan hukum atas nama rakyat, justeru mereka sendiri yang korup. Korupsi politik adalah ketika politik pengambil keputusan menggunakan kekuasaan politik mereka, untuk mempertahankan kekuasaan mereka, status dan kekayaan. Dengan demikian, korupsi politik dapat dibedakan dari korupsi birokrasi, yang merupakan korupsi dalam administrasi publik, pada pelaksanaan politik atau pengambilan kebijakan dibuat. Sementara korupsi politik melibatkan pembuat keputusan politik dan 
berlangsung di tingkat sistem politik, korupsi birokrasi (atau korupsi administratif) berlangsung pelaksanaan politik. Korupsi birokrasi tidak melibatkan politisi terpilih, tetapi melibatkan staf yang dipekerjakan dalam lingkup administrasi negara; layanan sipil, kementerian, dan penyedia layanan (termasuk kesehatan dan pendidikan, polisi dan bea cukai, transportasi dan sejumlah lembaga pelayanan negara lainnya. Di Indonesia, disepanjang tahun 2016 saja, ICW mencatat terdapat 216 Kasus yang telah masuk ke tahap penyidikan, sebagaimana ditunjukkan dalam tabel berikut

Tabel 2. Kasus Korupsi di Indonesia Tahun 2016

\begin{tabular}{|c|c|c|c|}
\hline Keterangan & $\begin{array}{l}\text { Jumlah } \\
\text { Kasus }\end{array}$ & $\begin{array}{c}\text { Nilai Kerugian Negara } \\
\text { (Rp Miliar) }\end{array}$ & $\begin{array}{l}\text { Nilai Suap ( } \\
\text { Rp Miliar) }\end{array}$ \\
\hline Penggelapan & 70 & 164 & \\
\hline $\begin{array}{l}\text { Kegiatan / Proyek } \\
\text { Fiktif }\end{array}$ & 34 & 246,8 & \\
\hline $\begin{array}{l}\text { Penyalahgunaan } \\
\text { Anggaran }\end{array}$ & 25 & 96,5 & \\
\hline Mark Up & 23 & 107 & \\
\hline $\begin{array}{l}\text { Penyalahgunaan } \\
\text { Wewenang }\end{array}$ & 19 & 218,1 & \\
\hline Mark Down & - & . & \\
\hline Laporan Fiktif & 13 & 14,6 & \\
\hline Suap / Gratifikasi & 15 & & 28,6 \\
\hline $\begin{array}{l}\text { Penyunatan / } \\
\text { Pemotongan }\end{array}$ & 8 & 37.4 & \\
\hline Pemerasan & 2 & 0.07 & \\
\hline Anggaran Ganda & - & - & \\
\hline Pungutan Liar & 1 & 0,17 & \\
\hline Pencucian Uang & 1 & 5,3 & \\
\hline TOTAL & 210 & 890,5 & 28,6 \\
\hline
\end{tabular}

Dengan demikian, korupsi merupakan tantangan etika saat ini dalam lingkup pemerintahan. Sebagaimana disebutkan Sebola (2014) bahwa masalah etika utama di sektor publikterkait dengan kegiatan korup yang merampokakses warga terhadap layanan publik. Beberapa ilmuan berpendapat bahwa tidak ada ancaman lain dari demokrasi, ekonomi dan politik di negara manapun yang lebih penting dari bahaya korupsi di masyarakat (Sandholtz dan Taagepera 2005; Mohammed 2013).

\section{Membangun Legitimasi Dan Kepercayaan Publik}

Terlepas dari perdebatan tersebut, sampai disini kita kemudian menyadari bahwa etika khususnya etika diruang publik menjadi sebuah keharusaan saat ini, bukan karena etika memang sesuatu yang wajib adanya melainkan lebih dari itu, etika memiliki tujuan bagi pembangunan kehidupan publik yang lebih baik. Ikeanyibe (2009, 199-200) memberikan beberapa alasan untuk itu, sebagai berikut:
1. Etika sebagai ilmu tindakan manusia melengkapi norma dimana hubungan antara orang diatur. Ini menunjukkan apa dan bagaimana hubungan tersebut dan menunjukkan alasan yang mengharuskannya untuk menjadi begitu.

2. Etika sebagai ilmu terapan merupakan dasar untuk bidang-bidang studi dan praktek, penting karena panduan / menetapkan kode etika membimbing tindakan manusia dalam berbagai aspek kehidupan.

3. Etika menegaskan kembali keunikan manusia di antara makhluk lainnya, mengingat fakta bahwa kehidupan diri manusia adalah konstruksi etis.

4. Untuk tingkat yang lebih besar, studi tentang etika memfasilitasi pembentukan sikap mendasar untuk kehidupan yang lebih baik. Pelatihan dalam etika harus memungkinkan kita untuk melihat kecacatan dalam tingkah laku kita sendiri dan orang lain dan untuk memahami sifat yang tepat untuk itu, sehingga kita lebih mampu mengatur hal yang benar dalam perilaku kita sendiri dan untuk membuat saran yang akan menguntungkan tidak hanya untuk diri sendiri melainkan juga untuk orang lain.

5. Etika berfungsi sebagai strategi sosial untuk meningkatkan kehidupan manusia melalui pelestarian ekosistem lebih manusiawi dan untuk mencapai harmoni sosial dan global. Dengan demikian memfasilitasi nilai-nilai sosial umum, penghargaan / memperkuat nilai-nilai positif.

6. Etika hakikatnya telah terjalin hubungannya dengan agama. Kebanyakan agama yang dibangun di atas prinsip dasar bahwa perilaku yang baik akan dihargai dan perilaku yang buruk / jahat dihukum. Hubungan etika ini dengan agama memberikan alasan utama untuk perbuatan yang benar dan keengganan untuk melakukan kejahatan. Ini sejalan dengan naluri manusia pada umumnya dalam beragama.

Dalam konteks penyelenggaraan negara di ruang publik, tentunya etika menuntut lebih dari sekedar etika pribadi. Sebagaimana disebutkan Meguid (2011) bahwa mempertahankan standar etika yang tinggi dalam pemerintahan tampaknya sangat penting. Hal itu bahkan dapat dikatakan bahwa standar etika ditetapkan agak lebih tinggi di pemerintahan daripada di sektor bisnis atau kehidupan pribadi. Hal ini karena pemerintah memiliki kewenangan untuk menuntutketaatan dari individu dan mewajibkan mereka bertindak dengan cara yang diinginkan (government power). Pemerintah membiayai operasinya dengan memungut pajak atas publik; Dengan demikian, pembayar pajak mengharapkan kejujuran dan integritas dari pemerintah. Administrator publik adalah instrumennyaNegara; Tindakan mereka adalah perpanjangan dari institusi pemerintah, hukum, dankebijakan. Apalagi, "administrator publik menjalankan kebijaksanaan saat mengukur masalah, perumusan kebijakan, dan pelaksanaan keadilan "(Davis, 1971). Pejabat eksekutif tingkat atas (juga pejabat politik) memiliki kekuatan yang sangat besar dalam lingkup pengaruh merekakhususnya dalam pembuatan kebijakan yang akan mempengaruhi masyarakat publik; sedangkan disisi lainnya, birokrasi di level bawah, atau yang sering dikenal dengan "street level bureaucracy" adalah wajah 
pemerintah di masyarakat publik dan Klien "(Lipsky, 1983).

Tata kelola etis dan kepercayaan memiliki hubungan timbal balik karena hubungan kepercayaan terhadap nilai etika dan mekanisme, yang secara otomatis membuat kepercayaan publik menjadi bagian dari tata kelola etis.Ini adalah fakta bahwa korupsi meningkat jika pedoman etika dan kode etik yang dapat digunakan sebagai contoh atau panduan tidak tersedia, tidak secara eksplisit dinyatakan atau jika petugas publik tidak mematuhinya (Ikola-Norrbacka et al., 2010: 79).Vigoda (2000), berpendapat bahwa memahami hubungan antara tata kelola etika dan kepercayaan publik dalam pengertian kontemporer merupakan aspek-aspek: (1) Pemeriksaan yang fokus pada unsur manusia dan sosial, (2) Dimensi Inovasi produktifdan kreativitas, dan (3) Aspek normatif moralitas dan etika. Relasi-relasi tersebut, sebagimana dapat dilihat dalam gambar berikut :

Gambar 2: Kepercayaan dan Etika Governance dalam Konteks Anti-Korupsi

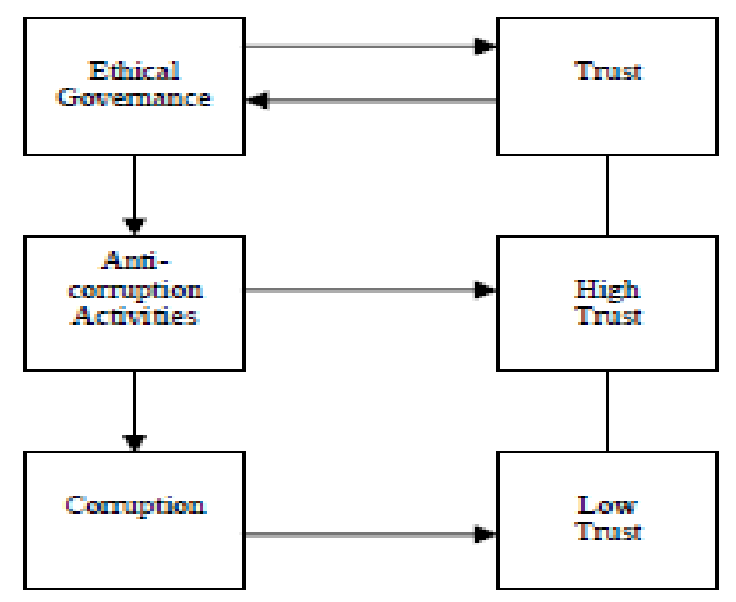

Dengan demikian, hal ini menunjukkan bahwa kepercayaan publik sebagai bagian dari tata kelola etis (governance ethics). Etika governance dalam hal ini merupakan sebuah konsep yang luas dengan dimensi yang berbeda dan memang demikian, terdiri dari nilai dan mekanisme etika khusus. Nilai dan mekanisme etis adalah sarana untuk mencapai kepercayaan, karena mereka adalah representasi etika pemerintahan. Etika governance adalah proses dan orientasi yang menjamin standar perilaku etis dan kinerja yang paling dapat diterima dan juga bisa didefinisikan sebagai nilai dan mekanisme yang menawarkan kebaikan bagi warga dan masyarakat. Selain itu, tata kelola etis berorientasi rasionalitas. Nilai adalah isu kebutuhan dan persepsi yang terkait dengan etika; Yang mencakup prinsip yang mengarahkan evaluasi kita terhadap apa yang baik dan ideal. Rasionalitas juga menyangkut pemikiran dan citacita kita,yang membahas masalah pilihan, preferensi, dan hasil.

Dalam artian ini, bahwa kepercayaan dalam konteks administrasi publik dan manajemen paling sering diikat melalui nilai kinerja dan mekanisme etika membantu dalam menginformasikan kepercayaan, karena kepercayaan publik terwujud atau meningkat bila aktivitas anti korupsi mampu mengurangi korupsi. Memerangi korupsi bisa mengambil pandangan ideologis, yang diwakili dengan orientasi hukum atau kebijakan dan prosedur; Dan pandangan institusional,Yang diwakili oleh badan antikorupsi. Pandangan Ideologis dan institusionalpaling tepat adalah saat mereka mematuhi nilai dan mekanisme etika (Osifo, 2012). Karenanya, penalaran moral oleh pegawai negara, diperlukan untuk menyeimbangkannilai dan tuntutan pemerintah yang bersaing di ruang publik. Administrator publik sering membuat keputusan yang kuat berdasarkan informasi yang tidak sempurna; Nilai etika administrator menginformasikan keputusan ini pada akhirnya, etika merupakan faktor sentral dalam debat yang telah berlangsung lama atas tanggung jawab administratif, responsif, dan akuntabilitas "(Frederickson, 1993).

Apalagi, misalnya Adams dan Balfour (2009) berpendapat bahwa ada kecenderungan untuk kejahatan administratif (administrative evils) yang ditenun menjadi identitas urusan publik dan bidang lainnya danprofesi dalam kehidupan publik. Kecenderungan ini dapat dimanifestasikan dalam tindakan dehumanisasi dan genosida dimana orang awam mengangganya bertindak normal. Peran profesional dan administratif, terlibat dalam tindakan kejahatan tanpa disadariItu adalah salah dan sebuah kejahatan moral. Lebih jauh mereka berpendapat bahwa "dalam kondisi konversi moral, manusia bahkan mungkin melihat aktivitas jahat mereka sama baiknya "(Adams dan Balfour, 2009) ${ }^{1}$. Atau bahkan misalanya seperti apa yang dikatakan Fredericson (1984) bahwa seringkali atas nama efisiensi dan efektifitas pemerintah mengabaikan aspek keadilan yang cenderung membuat deprivasi kelompok rentan.

Hal ini misalnya dengan jelas terlihat dari adanya perasaan diperlakukan tidak adil yang dialami oleh kelompok masyarakat di tengah berlimpahnya kekayaan alam, menimbulkan semacam keputusaasaan yang berujung pada tindakan delegitimasi. Padahal dimensi keadilan, merupakan nilai yang secara subtansial mendasar sebagai nilai utama moral dalam upaya mewujudkan legitimasi pemerintahan. Frederickson (1993) salah seorang pakar di bidang administrasi, menganjurkan diperhatikannya elemen keadilan sosial dalam administrasi publik selain efisiensi, efektifitas maupun ekonomi.

Keterbatasan atau ketiadaan keadilan sosial dalam lingkup pembahasan admnistrasi publik menyisahkan sebuah pertanyaan, efektifitas untuk siapa? Efiensi untuk siapa?. Kajian tentang keadilan menjadi sangat signifikan keberadaannya dalam New Public Admnistration (NPA), seperti yang ditulis Frederickson: " Dasar pemikiran untuk administrasi publik hampir senantiasa berupa manajemen yang lebih baik (lebih efisien ataupun lebih ekonomis). Admnistrasi publik baru menambahkan keadilan sosial pada sasaran-sasaran dan dasar pemikiran klasik". (1984:9). Tanpa keadilan, maka proses 
pelaksanaan sistim administrasi publik dan kebijakan akan mengalami proses alineasi kepada kelompok rentan, yang justeru menimbulkan masalah bagi lahirnya sikap militansi. Seperti dikatakan Fredericson (1984) lebih lanjut bahwa : “..Berlanjutnya deprivasi ditengah-tengah kekayaan menyebabkan timbulnya keputus-asaan dan semacamnya, kemarahan dan militansi. Suatu administrasi negara (public administration) yang gagal melakukan perubahan yang mencoba untuk menghadapi deprivasi ini pada akhirnya mungkin sekali akan digunakan untuk menindas golongan yang berkekurangan .." (Frederickson, 1959: 59).

Penilaian etis dengan demikian sangat ampuh karena menghasilkan motivasi moral yang pada gilirannya merangsang tindakan etis, atau lebih tepatnya pengambilan keputusan dan juga etika penyelenggaraan pelayanan publik. Menurut Meguid (2011) bahwa terdapat implikasi keterkaitan antara etika, motivasi, dan perilaku inisangat penting untuk memahami pentingnya etika, danhubungan antara penilaian moral, motivasi pelayanan publik, dan etika perilaku pemerintahan..

\section{PENUTUP}

\section{Simpulan}

Promosi etika penyelenggara negara ini, sebagaimana juga telah disebutkan diawal merupakan pemahaman tentang perilaku etis dalam pemerintahan, dan korupsi sebagai antitesisnya, telah menjadi isu hangat bagi organisasi internasional seperti UnitedBangsa, Bank Dunia, Dana Moneter Internasional (IMF), dan Organisasi untuk Kerjasama Ekonomi dan Pembangunan (OECD). Begitu pula dengan keprihatinan oleh banyak anggota Negara dan telah menempatkan penekanan khusus pada upaya melawan korupsi, dan mendorong perilaku etis di lingkungan pemerintahan. Dengan demikian, tema buku ini terkait dengan etika di ruang publik dimaksudkan untuk mengatasi adanya krisis legitimasi di ruang publik. Krisis legitimasi mengacu pada penurunan kepercayaan terhadap fungsi administratif, lembaga, atau kepemimpinan (Morris, 2001; Friedrichs, 1980; Christian, 2007).

Krisis legitimasi di ruang publik terutama terlihat dari lahirnya public distrus yang mengarah pada krisisis otoritas politik. Krisis kepercayaan publik dalam pemerintahan dan lembaga-lembaga telah melahirkan minat penelitian dalam 30 tahun terakhir (lihat, misalnya, Barber, 1988). Lebih dari itu, krisis kepercayaan kepada pemerintah merupakan jantung dari studi etika politik kontemporer. Sebagaimana Habermas (1975) dalam bukunya Legitimation Crisis, mengatakan bahwakrisis legitimasi adalah krisis identitas yang dihasilkan dari hilangnya kepercayaan lembaga administrasi, yang terjadi meskipun fakta bahwa mereka masih mempertahankan kewenangan hukum yang digunakan untuk mengatur masyarakat.

Dalam krisis legitimasi, struktur pemerintahan tidak dapat menunjukkan bahwa fungsi praktis mereka memenuhi peran mereka yang telah dilembagakan. Untuk melihat skema ini, kita mengasumsikan bahwa dalam subsistem dunia sosial politik membutuhkan masukan loyalitas massa untuk menghasilkan output, yang terdiri dari keputusan-keputusan administratif yang sah yang dijalankan oleh negara. Sebuah krisis rasionalitas adalah output krisis yang terjadi ketika negara gagal memenuhi tuntutan ekonomi. Krisis legitimasi, di sisi lain, adalah krisis masukan yang terjadi ketika "sistem legitimasi tidak berhasil mempertahankan tingkat yang diperlukan, loyalitas massa." Ini adalah krisis identitas di mana administrasi tidak dapat membangun struktur normatif sejauh yang diperlukan untuk seluruh sistem agar berfungsi dengan baik.

Akibatnya, negara mengalami kerugian melalui penurunan dukungan oleh masyarakat-publik yakni manakalamasyarakat menilai administrasi sudahtidak akuntabel lagi (Habermas, 1975). Hal ini pada akhirnya berdampak pada kehilangan kepercayaan publik, di mana salah satu dari sekian banyak karakteristik dari krisis legitimasi, di antaranya adalah isu-isu inkoherensi kebijakan dan kehilangan kemauan institusional (Held, 2006).

Sampai disini kita melihat bahwa kepercayaan dapat dilihat sebagai bagian penting dari komunitas moral manapun. Jika demikian, maka setiap komunitas politik yang membidik legitimasi dipaksa untuk menjaga hubungan yang dapat dipercaya antar warga negara (Abo Akademi, 2008). Tidak ada rezim yang substansial dapat bertahan hidup tanpasumber daya berupa jaringan kepercayaan. Secara khusus, rezim demokrasi tidak bisaberoperasi tanpa integrasi besar jaringan kepercayaan dalam politik publik (Tilly, 2004) dan legitimasi (Lipset, 2007). David Easton (1965:278) menegaskan adanya sebuah kebutuhan legitimasi (the need for legitimacy) bagi sebuah rejim dan otoritas publik.

Dalam pandangan filsafat politik klasik atau tradisional, tidak ada suatu sistim yang dapat bertahan tanpa adanya legitimasi. Legitimasi adalah alat yang paling efektif untuk memberikan dukungan bagi rejim dan otoritas publik (Easton, 1965:278). Foreign Policy (Lembaga 'The Fund For Peace') bahkan menjadikan faktor legitimasi (delegitimasi) sebagai salah satu indikator dari kegagalan Negara (indikator ke 7). Sebagaimana disebutkan dalam laporannya untuk tahun 2007 misalnya, Indonesia menempati urutan ke 55 sebagai Negara delegitimet (tidak legitimet).

Sedangkan secara keseluruhan pada tahun 2010, Indonesia menempati urutan atau rangking 61 dengan skor 83.1 sebagai kategori Negara gagal (www.foreignpolicy.com). Dalam hal ini, dipahami bahwa seorang warga dapat tunduk dan patuh (atau memberikan dukungan) kepada sebuah rejim dan otoritas publik dengan berbagai alasan yang berbeda-beda. Akan tetapi dukungan yang paling stabil adalah bersumber dari sebuah keyakinan bahwa regim dan otoritas publik tersebut memang berhak dan pantas (Easton, 1965:278).

Otoritas publik dalam artian ini akan kehilangan legitimasinya dan cenderung melahirkan konflik baik vertikal maupun horizontal adalah karena strategi kebijakan baik pada level struktural maupun subtansi dan 
kultural tidak memperkuat nilai-nilai demokratis. Demokrasi hanya menjadi slogan dalam bahasa puitis para elit pemangku kebijakan saja. Terdapat sebuah asumsi bahwa kegagalan sebuah kebijakan ataupun Negara melalui instrumen kebijakannya bukanlah semata persoalan tekhnis implementasi melainkan lebih karena persoalan kegagalan institusi berikut 'aparatur'. Glazer dan Rothenberg (2001) dalam menyebutkan beberapa konsep-konsep aparatur yang menjadi kendala (constraint) bagi kesuksesan kebijakan menyebutkan bahwa faktor integritas aparat menjadi faktor pertama yang menjadi hambatan kesuskesan kebijakan (Glazer dan Rothenberg 2001:6).

Meskipun demikian, faktor administrasi, manajerial dan implementasi bukanlah faktor yang tidak penting sehingga dapat diabaikan keberadaannya, karena implementasi juga berkaitan erat dengan legitimasi. Kegagalan implementasi karena adanya faktor kegagalan instrumen kebijakan dapat mengakibatkan defisit legitimasi. Faktor ini memang bukanlah faktor langsung melainkan bersifat perantara di mana aparatur dapat dinilai dari fungsi manajerialnya ini. Yang tidak bisa ditolak adalah peran manusia--aparatur dalam hal ini adalah mutlak. Administrator publik memiliki peran dan fungsi yang cukup berat dalam kebijakan publik, karena memainkan tugas dan peran ganda yakni politik dan administrasi.

Gabungan diantara keduanya dapat saja melahirkan tindakan politisasi administrasi. Politisasi administrasi lahir dari kenyataan bahwa fungsi administrasi bersifat netral dalam bertindak dan mengimplementasikan garis-garis besar tujuan politik atau dijadikan sebagai instrumen pemenuhan hasrat politik para aktor administrator (politik dalam arti “negatif”). Lebih lanjut, Yudi Latif (2011) dalam mengutip Burnell dan Randell (2008) mengenai kegagalan Negara mengatakan: "Negara gagal dicerminkan ketakmampuannya mengorganisasikan aparatur-nya secara efektif, yang mengarah kepada kekacaubalauan politik (political disorder). Hal ini ditandai dengan ketidakjelasan otoritas politik, ketidakefektifan administrasi publik, dan merajalelanya korupsi, legitimasipun memudar"3.

Krisis Otoritas publik sebagai sebuah rezim bukanlah tanpa sebab, melainkan dimulai pada aspek kebijakan dan tannggungjawab Negara melalui kebijakan publiknya tidak klop-singkron. Negara melalui tugas dan kewajibannya pada aspek vital sebagaimana disebutkan oleh Fukuyama, Chomsky dan Ghani-Lockhart sulit untuk diwujudkan. Kebijakan publik yang idealnya adalah bertujuan untuk menyeselaikan serangkaian persoalan dalam kehidupan publik. Sehingga dengan demikian, kebijakan sejatinya harus memiliki nilai-nilai orientasi yang bersifat humanistik dan tidak sekedar bersifat instrumental. Perubahan kebijakan (policy reform) dengan demikian haruslah dapat memperhatikan nilai-nilai yang subtansial dan mendasar bagi kehidupan manusia secara keseluruhan. Negara dengan demikian memiliki serangkain tugas dan kewajiban primer yang dapat dipenuhi melalui intrumen kebijakannya.

Lahirnya otonomi daerah yang dinilai oleh para ahli dapat meningkatkan kesejahteraan rakyat sepertinya masih jauh dari harapan. Perubahan struktur pemerintahan dari model sentralistik menuju desentralisasi, bukan tidak mungkin membuka peluangpeluang konflik apabila tidak dikelola dengan baik. Sumbernya adalah terbukanya keran-keran baru bagi posisi masyarakat yang selama ini tertekan dalam kurun waktu yang begitu lama (masa orde baru). Baechler mengungkapkan bahwa reformasi negara dan konflik secara erat berhubungan.

Sejauh ini, otonomi daerah hanya sekedar menjadi simbolis dan secara prakmatis tidak memberikan perubahan signifikan pada sisi kehidupan secara utuh selain aspek kecil dari sistim manajerial dan euphoria semata seperti pemilihan langsung, dan sebagainya. Sementara reformasi Negara disatu pihak dapat dilihat sebagai prasyarat untuk transformasi konflik dan perdamaian yang berkelanjutan melalui partisipasi, juga dapat dengan mudah menjadi sumber konflik apabila praktik kebijakan publik daerah yang berlangsung cenderung semakin mempertegas deprivasi masyarakat lokal. Sebenarnya, Potensi reformasi Negara itu sendiri itu dapat dilihat sebagai sesuatu yang bersifat positif, tergantung pada pembentukan struktur yang tepat, nilai dan sikap yang memungkinkan berbagai kelompok dalam masyarakat untuk menangani konflik mereka secara damai (Baechler, 2004:2).

\section{Saran}

Dengan demikian, reformasi Negara harus dalam hal apapun meliputi lebih dari sekedar re-organisasi dari system administrasi atau cara di mana sumber daya yang dialokasikan. Sebaliknya, ia harus mengatur panggung atau arena untuk pembentukan proses pembangunan bangsa yang partisipatif dan legitimet (Baechler, 2004:2). Sebuah demokrasi perlu dikembangkan karena dianggap mampu untuk mengatasi ini melalui penerapan nilai-nilai partisipasi, memiliki efek menenangkan karena didasarkan pada nilai-nilai seperti pluralisme, inklusivitas toleransi, dan kompromi, dan karena itu membantu untuk menetapkan norma-norma perilaku seperti negosiasi, kompromi dan kerjasama antara para pelaku politik (Bachler, 2004:2). Untuk tujuan itu, Bachler (2004) mengusulkan beberapa strategi diantaranya adalah evaluasi pendekatan partisipatif untuk penyelesaian sengketa yang khusus dirancang untuk mengurangi kinerja negara yang buruk, untuk melengkapi aturan hukum dan untuk mengatasi kekurangan dalam struktur masyarakat yang dapat menyebabkan konflik. Dengan demikian, demokrasi menjadi basis bagi pengambilan keputusan politik dan tidak sekedar sebagai rutinitas tanpa makna dalam pemilihan umum saja. Makna representasi akan tampak dalam keterwakilan kepentingan dan bukannya keterwakilan personal. Kualitas-atau subtansi 
dan bukan kuantitas dan prosedural belaka. Dengan tegas, Anthony Giddens mengatakan: "tidak ada otoritas tanpa demokrasi” (2002:75).

\section{DAFTAR PUSTAKA}

Abrahamsen, R. (2000). Disciplining democracy. London: Zed Books.

Adams, Guy B. (2000). An Administrative Ethics and the Chimera of Professionalism: The Historical Context of Public Service Ethics. @ In Handbook of Administrative Ethics, edited by Terry L. Cooper. Second edition. New York: Marcel Dekker.

Akers, J. (1989). "Ethics and competitiveness putting first things first". Sloan Management Review, 30(2), 69-71.

Amundsen, Inge dan Vicente Pinto de Andrade. (2009), Public Sector Ethics, Compendium for teaching at the Catholic University of Angola.

Aristotle. (1980). The Nicomachean ethics. (D. Ross, Trans.). Oxford and New York: Oxford University Press.

Appleby, P.H. (1952). Mortality and Administration in Democratic Government. Louisana State University Press, Baton Rouge, Louisana.

Berman, Evan M. and Jonathan P. West, 1997. "Managing Ethics to Improve Performance and Build Trust." Public Integrity Annual, 23-31.

Brudney, Jeffrey L. and J. Michael Martinez, (2010). Teaching Administrative Ethics in Nonprofit Management: Recommendations to ImproveDegrees, Certificates, and Concentration Programs, Journal of Public Affairs Education. JPAE 16(2): 181-206.

Bowman, J. (1997). Ethics in government: From a winter of disparity a spring of hope. Public Administration Review, 57 (6), 517-526.

Bowie, Norman E. (1981). Ethical Issues in Government. Philadelphia: Temple University Press.

Burke. Lanham, Maryland: Rowman \& Littlefield Publishers Inc.Caiden, Gerald E., O.P. Dwivedi, \& Joseph G. Jabbra (Eds) (2001). Where Corruption Lives. Bloomfield: Kumarian Press.

Caufield, C. (1996). Masters of illusion: The World Bank and the powers of nations. New York:Henry Holt and Co. Inc.

Cooper, Terry L. (1998). The Responsible Administrator. San Francisco: Jossey-Bass Publisher.

Cooper, Terry L. (Ed) (2001). Handbook of Administration. New York: Marcel Dekker.

Cooper, Terry L. (2004). Big Questions in Administrative Ethics: A Need for Focused, Collaborative Effort. Public Administration Review 64: 4, 395-407.

Caiden, Gerald E. (2001). Corruption and Governance. In: (Understanding Fraud,Waste, and Corrupt
Practices). In: Combating Corruption, Encouraging Ethics: A Practical Guide to Management Ethics, 1? 10. Eds William L. Richter \& Frances

Denhardt, K.G. (1988). The Ethics of Public Service. Greenwood Press, New York.

Dwivedi, O. P.. (1995). "Reflections on Moral Government and Public Service as a Vocation." Indian Journal of Public Administration 41(3):296306.

Frederickson, H. George (1993): Ethics and Public Administration. Armonk, NY: M. E. Sharpe.

Frederickson, George H. \& David K. Hart (1985). The Public service and the Patriotism of Benevolence. In: Classic of Administrative Sayre, Wallace S. (1951). Trends of a Decade in Administrative Values. In: Classic of Administrative Ethics, 48-62. Ed. Willa Bruce. Colorado etc.: Westview Press

Giddens, Anthony, (terjemahan). (2009). Problematika Utama dalam teori Sosial: aksi, struktur dan kontradiksi dalam analisis sosial, Pustaka Pelajar, Yogyakarta.

Graham, Gordon (2014). Teori-teori Etika, Nusamedia, Bandung.

Giddens, Anthony, (2002), Jalan ke Tiga: Pembaruan Demokrasi Sosial [The Third Way: The Renewal of Social Democracy], diterjemahkan oleh Ketut Arya Mahardika (Jakarta: Gramedia Pustaka Utama, 2002.

Garofalo Charles \& Dean Geuras, (2006). Common Ground, Common Future: Moral Agency In Public Administration, Professions, And Citizenship, Taylor $\&$ Francis. NY.

Geuras, Dean \& Charles Garofalo (2005). Practical Ethics in Public Administration. Virgina: Management Concept Inc.

Gilman, S. C., and Lewis, C. W. "Public Service Ethics: A Global Dialogue." Public Administration Review, 1996, 56(6), 517-524.

Gilman, Stuart C. (2005). Ethics Codes And Codes Of Conduct As Tools For Promoting An Ethical And Professional Public Service: Comparative Successes And Lessons. Prepared For The Prem, The World Bank, Washington, DcWinter 2005.

Gortner, Harold F. (1991). Ethics for public managers. New York: Praeger.

Gortner, Harold F. (1995). Ethics and public personnel administration. Public personnel administration: Problems and prospects, 3d edition, ed. Hays, Steven W. and Richard C. Kearney, 273-288. Englewood Cliffs: Prentice Hall.

Gortner, Harold F. (2000). Values and ethics, in Handbook of administrative ethics, $2 d$ edition, ed. Terry L. Cooper, 509-554. New York: Marcel Dekker. 
Goodsell, C.T. (1990). Public administration and the public interest. In G.L. Wamsley et al. (Eds.), Refounding public administration (pp.96-113). Newbury Park, CA: Sage Publications.

Kavran, Dragoljub \& Sherman M. Wyman (2003). "Ethics Or Corruption? Building A Landscape For Ethics Training In Southeastern Europe".

Kernaghan, Kenneth (1997). Towards a Public-Service Code of Conduct - and Beyond. Canadian Public Administration 40:1, 40-54.

Kernaghan, Kenneth (1996). The Ethics Era in Canadian Public Administration.

Lele, Gabriel (2010). "Peningkatan kapasitas etika dalam mendorong perwujudan Good Governance",dalam Wahyudi Kumorotomo dan Amar Widianingrum (Editor), Reformasi aparatur negara ditinjau kembali, 2010, Gava Media, Yogyakarta.

Langford, John W. (2004). "Acting on values: an ethical dead end for public servants:, Canadian Public Administration 47:4, 429-450.

Lehtonen, Tommi (2010). Ethical Governance from a Citizen's Point of View: A Care-Ethical Approach. In: Ethical Governance: A Citizen Perspective, 2841. Ed. Ari Salminen. Proceedings of the University of Vaasa. Research Papers 294. Public Management 39. University of Vaasa: Publication Unit.

Lähdesmäki, Kirsi (2010). Fair Society and Political Participation as Parts of Good Governance: The Views of Finnish Youth. In: Ethical Governance: A Citizen Perspective, 63-75. Ed. Ari Salminen. Proceedings of the University of Vaasa. Research Papers 294. Public Management 39. University of Vaasa: Publication Unit.

Lähdesmäki, Kirsi \& Ari Salminen (2009). Ethics: Does It Play a Role in the Finnish University Reform. Administrative Studies 28:3, 48-61.

Maesschalck, J. (2004). "Approaches to Ethics Management in thePublic Sector: A Proposed Extension of theCompliance-Integrity Continuum", Public Integrity, Winter 2004-5, vol. 7, no. 1, pp. 21-41.

Menzel, Donald C. (2007). Ethics Management for Public Administrators: Building Organisations of Integrity. New York: M. E. Sharpe.

Nabatchi, Tina (2011). Four Frames for Understanding Public Values in Administration and Governance ,Paper prepared for the Public Manage ment Research Conference Maxwell School, Syracuse Unive rsity, June 2-4, 2011.

OECD, (2000),Trust in Government: Ethics Measures in OECD Countries, OECD Publishing.

Pevkur, Aive. (2006).Interrelations in the implementation of systems of integrity, ethics, and public adminstration. Paper presented to the international conference "Leadership, Ethics and Integrity in Public Life", WEF April 9-12, Keble College, University of Oxford, UK.

Radhika, D. (2012). "Ethics in Public Administration "Journal of Public Administration and Policy Research Vol. 4(2) pp. 23-31 March, 2012.

Rashid, Sadia dan Uzma Rashid (2012). "Work Motivation Differences between Public and Private Sector", American International Journal of Social Science Vol. 1 No. 2; December 201224.

Simola, Scheldene K., Julia Barling, \& Nick Turner (2010). Transformational Leadership and Leader Moral Orientation: Contrasting an Ethic of Justice and an Ethic of Care. Leadership Quarterly 21, 179188.

Sindane, A.M. (2011). Values and ethics enter the real world: a framework for public leadership and Governance. Koers 76(4) 2011:751-769

Sorensen, G. (Ed.) (1993). Political conditionality. London: Frank Cass.The Problem of Dirty Hands: Can Public Guilt Produce Public Awareness?

Svara, James. (2014). The Ethics Primer for Public Administrators in Government and Nonprofit Organizations. Sudbury, MA: Jones and Bartlett Publishers.

Suchman, Mark(1995). "Managing Legitimacy: Strategic and Institutional Approaches". The Academy of Management Review. 20 (3): 571-610.

Thompson, Dennis F. (1985). The Possibility of Administrative Ethics. In: Classic of Administrative Ethics, 79-92. Ed. Willa Bruce. Colorado etc.: Westview Press.

Thompson, Fred \& Lawrence R. Jones (2007). Cultural Evolution of Organizations from Bureaucracy to Hyperarchy and Netcentricity: Reaping the Advantages of it and Modern Technology. In: Cultural Aspects of Public Management Reform, 203-230. Eds Kuno Schedler \& Isabella Proeller. Amsterdam: JAI Press.

Tilly, Charles (2005). Trust and Rule, Cambridge University Press

Thoha, Miftah, (2010), Birokrasi \& Politik di Indonesia, Rajagrafindo Persada, Jakarta.

Thoha, Miftah, (1995), Birokrasi Indonesia Dalam Era Globalisasi, Pusdiklat Pegawai Depdikbud, Sawangan-Bogor.

Uhr, John (1994). Managing the Process of Ethics Training. In: Ethics for the Public Sector. Education and Training, 161-178. Ed. Noel Preston. Maryborough: The Federation Press.

Uhr, John. (1988). "Ethics and Public Service", Australian Journal of Public Administration, 67. 
Uslaner, E. (2002) The Moral Foundations of Trust. Cambridge: Cambridge University Press.

Van Wart, Montgomery(1996): The Source of Ethical Decision Making for Individuals in the Public Sector. Public Administration Review, pp 525-533.

Van der Waldt, G. \& Helmbold, R. (1995). The constitution and a new public administration. Cape Town: Juta \& Co. Ltd

Winter, Gibson (1966). Elements for a Social Ethics. New York: Macmillian.

Yusuph, Mashala Lameck; Wang Guohua; Ahmed Ramadhan Abeid (2016). "Code of Ethics and Conducts in Public Service: The Litmus Test for Public Administrators Ethical Decision Making in Resolving Ethical Dilemmas: A Comparative Study of Tanzania and South Africa", IOSR Journal of Business and Management (IOSR-JBM) e-ISSN: 2278-487X, p-ISSN: 2319-7668. Volume 18, Issue 12. Ver. III (December. 2016), PP 79-87 